ISSN 0103-5150

Fisioter. Mov., Curitiba, v. 24, n. 4, p. 629-636, out./dez. 2011

Licenciado sob uma Licença Creative Commons

\title{
Quadriceps short-term resistance exercise in subjects with resistant hypertension
}

\author{
Exercícios em curto prazo de resistência no quadríceps \\ em indivíduos hipertensos refratários
}

\author{
Arthur de Sá Ferreira ${ }^{[a]}$, Juliana Flávia de Oliveira $^{[b]}$, Ivan Cordovil ${ }^{[c]}$, José Barbosa Filho ${ }^{[d]}$ \\ [a] Fisioterapeuta, Doutor em Ciências em Engenharia Biomédica, professor adjunto do Centro Universitário Augusto \\ Motta, Laboratório de Análise do Movimento Humano, Programa de Pós-Graduação em Ciências da Reabilitação, Centro \\ Universitário Augusto Motta (Unisuam), Rio de Janeiro, RJ - Brasil, e-mail: arthurde@profunisuam.com.br \\ [b] Fisioterapeuta, Doutora em Ciências (Clínica Médica), professora adjunto do Centro Universitário Augusto Motta, \\ Laboratório de Desempenho Cardiovascular e Respiratório, Programa de Pós-Graduação em Ciências da Reabilitação, \\ Centro Universitário Augusto Motta (Unisuam), Rio de Janeiro, RJ - Brasil, e-mail: julianaflavia@profunisuam.com.br \\ [c] Médico, Mestre em Medicina (Cardiologia), professor da Universidade Gama Filho, chefe da Divisão de Hipertensão \\ Arterial, Instituto Nacional de Cardiologia, Rio de Janeiro, RJ - Brasil, e-mail: ivancordovil@cardiol.br \\ [d] Médico, Doutor em Medicina (Clínica Médica), professor da Universidade Gama Filho, pesquisador da Divisão de \\ Hipertensão Arterial, Instituto Nacional de Cardiologia, Rio de Janeiro, RJ - Brasil, e-mail: jbmfilh@gmail.com
}

\begin{abstract}
Introduction: Resistant arterial hypertension may lead to muscle disuse and reduced functional capacity due to arterial and target-organs lesions. The main objective of this work is to evaluate the quadriceps strength and fatigue tolerance after a program of resistance exercise in subjects with resistant primary hypertension. Methods: Six patients under pharmacological treatment were submitted to a four-week resistance exercise training program for the quadriceps (8-14 repetitions, 3 sets, 3 days per week). Strength was evaluated by isometric dynamometry, as the percentage change in maximum voluntary contraction over the four week program. Fatigue was analyzed by surface electromyography, as the change in both root mean square value and intercept of median frequency slope of vastus medialis and vastus lateralis. Results: Significant increase in the maximum voluntary contraction was observed $(\mathrm{p}=0.04)$. Fatigue tolerance was not improved as seen by root mean square as well as in the intercept of median frequency ( $p>0.05$ ). Additionally, no significant changes were observed in resting arterial blood pressure and heart rate throughout the training period. Conclusion: The prescribed protocol seemed to successfully increase
\end{abstract}


localized muscle strength without negatively affecting the monitored cardiovascular variables in patients with resistant hypertension under pharmacological treatment.

Keywords: Electromyography. Median frequency. Cardiovascular diseases.

\section{Resumo}

Introdução: A hipertensão arterial resistente pode levar ao desuso muscular e redução da capacidade funcional devido a lesões arteriais e de órgãos-alvo. O objetivo deste trabalho é avaliar a força muscular e resistência à fadiga do quadríceps em indivíduos com hipertensão primária resistente após um programa de exercícios de resistência. Métodos: Seis pacientes sob tratamento farmacológico foram submetidos a um programa de treinamento muscular do quadríceps por 4 semanas (8-14 repetições, 3 séries, 3 dias por semana). Força foi avaliada por meio de dinamometria isométrica e apresentada como o percentual de alteração na contração voluntária máxima ao longo do programa de treinamento. Fadiga foi analisada por meio da eletromiografia de superfície como a alteração tanto na raiz quadrática média e no ponto de interceptação da inclinação da frequência mediana dos músculos vasto lateral e medial. Resultados: Foi observado aumento significante na força isométrica máxima $(p=0,04)$. A tolerância à fadiga não foi alterada, como evidenciado pela raiz quadrática média ou interceptação da frequência mediana $(p>0,05)$. Adicionalmente, não foram observadas alterações significativas na pressão arterial de repouso e frequência cardíaca ao longo do programa. Conclusão: o protocolo prescrito aumentou a força muscular localizada sem alterar negativamente as variáveis cardiovasculares monitoradas nos pacientes com hipertensão resistente sob tratamento farmacológico.

Palavras-chave: Eletromiografia. Frequência mediana. Doenças cardiovasculares.

\section{Introduction}

Primary hypertension is a condition resulting from complex polygenic mechanisms expressed by environmental factors $(1,2)$. Resistant hypertension is a disorder in which blood pressure cannot be reduced below target levels in patients who are compliant with an optimal triple-drug treatment (3) and affects $1-13 \%$ of the general population (4). The arterial system shows early pathological signals caused by the sustained stimulus of high blood pressure before the occurrence of target-organ lesions (5). Arterial adaptations include stiffening of large arteries, hypertrophied or remodeled medium-sized arteries $(6,7)$, and small vessels $(8$, 9), capillary rarefaction $(9,10)$, skeletal muscle insulin resistance (9), and impaired flow-mediated dilation mainly related to endothelial dysfunction. Altogether, these pathological changes increases wave reflections and raises pulse pressure, while reducing the blood flow to cardiac and skeletal muscles. With the progression of hypertension, patients become severely limited in their daily activities, leading to reduced functional capacity, muscle disuse and serious secondary conditions.
Physical inactivity is a well documented modifiable risk factor for cardiovascular diseases $(2,11)$. Regular aerobic exercise has been extensively described as an important factor on the prevention of cardiovascular events $(12,13)$. Likewise, resistance exercise has favorable effects on muscular strength and endurance, cardiovascular function, metabolism, coronary risk factors, and psychosocial well-being (14). The regular practice of physical exercise is the main non-pharmacological therapeutic approach of physical therapists for the treatment of subjects with high blood pressure and other co-morbidities, potentially reducing the risk factors associated with metabolic and musculoskeletal disorders. However, literature data support the therapeutic effects of a program of resistance exercise in patients with hypertension (13) but no data is available related to resistant hypertension. Hence, the potential benefits of a regional resistance exercise program in patients with resistant hypertension are still unclear.

The aim of this study is to evaluate the acute effects of a four-week localized resistance exercise program in muscle strength and fatigue tolerance in patients with resistant hypertension under pharmacological treatment. Additionally, the overall effects 
of the training program on hemodynamic variables will be assessed in this pilot study.

\section{Methods}

Subjects

This study was conducted at the Division of Arterial Hypertension in the National Institute of Cardiology (Rio de Janeiro, Brazil) and was carried out as a prospective trial. The experimental protocol was approved by the Institutional Review Board (CEP number 0142/23.03.07) and followed resolution 196/96. All participants signed the informed consent form after a detailed explanation about the measurement procedures.

Ten people with clinical diagnosis of resistant hypertension were interviewed to enroll in this pilot study. Three patients did not meet one of the following inclusion criteria: 55 years or less or availability of five weeks to complete the exercise program. The exclusion criteria were determined, according to a previous study (12) as follows: smokers, musculoskeletal disease, severe stenotic or regurgitant valvular disease, hypertrophic cardiomyopathy, dilated cardiomyopathy, myocardial ischemia, severe cardiac arrhythmias, or unstable angina. During the followup, one patient interrupted the program with symptoms of heart failure. Six volunteers completed the study, and their characteristics are listed in Table 1.

The participants did not interrupt their pharmacological treatment, and no washout was conducted prior clinical evaluations. Individuals were instructed not to join any other regular physical activity during the study. All individuals were requested to abstain from alcohol and caffeine consumption at least since 12 hours before their testing sessions.

\section{Procedures}

The protocol followed recommendations for resistance exercise $(12,15-17)$ except for load prescription. Individuals participated in a home-based program of quadriceps dynamic exercises performed bilaterally, three times a week for four weeks starting on Week 0 (preprogram measurements). This duration was chosen to evaluate the acute effects of the protocol in muscle strength and cardiovascular parameters. Follow-up telephone calls were conducted every two days from Week 0 until the $4^{\text {th }}$ week for assessment of any issue related to exercise execution. Each training session comprised three sets of a crescent number of repetitions along four consecutive weeks (8-10-12-14 repetitions for Weeks 1-2-34 , respectively) of concentric-eccentric contractions of knee extensors, separated by 30 seconds of rest. Individuals were instructed to completed every repetition in a slow and controlled manner. They were also instructed to avoid Valsalva maneuvers during each repetition. The protocol was performed with the individuals in a sitting position with folded arms across their chest. Resistance was performed by ankle-weights providing a fixed load of $3 \mathrm{~kg}$ (representing approximately $6 \%$ of median $100 \%$ MVC at

Table 1 - Six volunteers

\begin{tabular}{lccccc}
\hline Patient & Sex & Age, years & $\begin{array}{c}\text { "Pressure, } \mathbf{m m H g} \\
\text { (systolic/diastolic)" }\end{array}$ & Height, cm & Body mass, kg \\
\hline 1 & Male & 38 & $145 / 90$ & 170 & 77 \\
2 & Female & 51 & $190 / 140$ & 171 & 62 \\
3 & Male & 52 & $150 / 90$ & 170 & 77 \\
4 & Female & 55 & $230 / 170$ & 148 & 82 \\
5 & Female & 44 & $175 / 100$ & 143 & 70 \\
6 & Female & 42 & $170 / 100$ & 158 & 56 \\
Median & & 47.5 & $172.5 / 100.0$ & 162 & 73.8 \\
{$[$ Min; Max] } & & {$[38-55]$} & {$[145-230] /[90-170]$} & {$[143-171]$} & {$[56-82]$} \\
\hline
\end{tabular}

Source: Research data. 
Week 0). This small load was chosen to allow patients to execute the exercises at home, and to stimulate the continuity of the exercises after the study.

\section{Data Acquisition}

The system for signal acquisition comprises a personal computer and an 8-channel, 14-bits analogto-digital (A/D) converter board (NI-6009, National Instruments) with USB connection. The A/D converter was connected to a 4-channel preamplifier (EMG System $^{\text {TM }}$ do Brasil) for SEMG signal (gain 100, CMRR $>100 \mathrm{~dB}$, input impedance $10^{9} \Omega$ ). Also, the A/D converter was connected to a dynamometer (load cell, range 0-200 kg; EMG System ${ }^{\mathrm{TM}}$ do Brasil) for acquisition of isometric force signal. Pre-gelled Ag/AgCl disposable double-electrodes (interelectrode distance $=20 \mathrm{~mm}$; Hal Eletrodos) were connected with differential pre-amplified (gain 20) bipolar electrodes. Surface electromyography signals (SEMG) signals were acquired simultaneously at $1 \mathrm{kHz} /$ channel using SuiteMYO ${ }^{\mathrm{TM}}$ ( $\mathrm{PhD}^{2}$ Consultoria e Sistemas, Brazil).

Electrodes were fixed with adhesive tape to reduce noise due to skin movement artifacts. Before electrode placement, the skin area was cleaned with alcohol and abraded with coarse gauze to reduce skin impedance. Positioning of the electrodes followed international recommendations (18): a) Vastus Medialis (VM): placed at $80 \%$ on the line between the anterior spina iliaca superior and the joint space in front of the anterior border of the medial ligament; b) Vastus Lateralis (VL): placed at $2 / 3$ on the line from the anterior spina iliaca superior to the lateral side of the patella. Reference electrode was placed around the ankle. These two muscles have been chosen because of their morphology, superficial location, and association to daily living activities such as gait. Rectus femoris was not considered because it is a pennate muscle (it is difficult to align the detection system with the muscle's fiber direction, thus leading to incorrect estimation of SEMG variables), while the intermedius muscle is too deep to be detected with surface techniques.

Before determination of maximal voluntary contraction (MVC), a warm-up routine was performed consisting of ten active knee flexion-extensions. Individuals then performed three trials of maximal voluntary effort, isometric knee extension contraction at $60^{\circ}$ knee angle $\left(0^{\circ}=\right.$ full extension $)$ for 5 seconds each with 30 seconds of interval $(18,19)$. During trials, they were orally encouraged to produce MVC, and SEMG signal at the screen monitor was available as a feedback signal. A dynamometer (load cell) was connected to the ankle by a non-elastic strap to record the isometric output force. Special attention was given for the position of the load cell (perpendicular to the movement axis). The maximum isometric strength among three trials was selected as the $100 \%$ MVC of each subject.

Following a 3 minute resting period after MVC test, a fatigue test was performed. Individuals were asked to sustain a resistance level equivalent to $50 \%$ of the actual MVC during 60 seconds. Accordingly to a previous study, this level presents the highest SEMG signal variable repeatability (20). Again, the signal was displayed on the computer screen as a feedback signal, and a reference line was exhibited to indicate the expected force level.

The SEMG was performed weekly, between 8:00 a.m. to 12:00 a.m. (24h). Arterial blood pressure was measured in a sitting position, using a mercury-column sphygmomanometer at each visit to the ambulatory. Preceding the signals acquisition, the individual rested for 5-10 minutes in supine position for clinical evaluation. Heart rate was measured from blood pressure signals acquired non-invasively with a previously developed system (7). Both blood pressure and heart rate were measured at rest, i.e., pre-exercise. Blood pressure and heart rate were checked after every set on clinic visits and used for assessment of clinical status but not stored for statistical analysis. All individuals were familiarized with the process one week before joining the muscular conditioning program.

\section{Signal Processing}

Muscle strength was assessed by the maximal effort produced between trials at each week. SEMG signals were DC removed, bandpass filtered (10-450 $\mathrm{Hz}$ ), and notch-filtered from 59-61 Hz (and harmonics until $450 \mathrm{~Hz}$ ) using a second-order zero-lag-phase Butterworth filter. Root Mean Square Value (RMS) and Median Frequency (MDF) were estimated (20, 21) within periods of muscle activation automatically segmented using the load cell signal as a reference when force level was equal to $50 \%$ of the MVC. $\mathrm{RMS}_{\% \mathrm{VM}}, \mathrm{MDF}_{\% \mathrm{VM}}, \mathrm{RMS}_{\% \mathrm{VL}}$, and $\mathrm{MDF}_{\% \mathrm{VL}}$ represents 
RMS and MDF normalized values for VM and VL muscles, respectively. MVC, RMS and MDF percentage values were normalized regarding the same measured variables on Week 0 (preprogram measurements).

Muscle fatigue was evaluated by changes in intercepts of the linear regression of MDF over time for both $\mathrm{VM}$ and $\mathrm{VL}$, represented as $\mathrm{MDF}_{\mathrm{VM}-\text { INTERCEPT }}$ and $\mathrm{MDF}_{\mathrm{VL}-\mathrm{INTERCEPT}}$, respectively. Epochs of 1 second were used for fatigue analysis since the signal could be considered stationary. These variables are presented as normalized values regarding the intercept value of the linear regressions acquired at the Week 0 $(21,22)$.

\section{Assessment of home-based exercise program safety}

Individuals were asked on every visit from Week 1 to 4 to indicate whether the executed home program induced any adverse effects. More specifically, they were instructed to report about joint discomfort or pain, muscle soreness, fatigue, and dyspnea.

\section{Statistical Analyses}

Friedman test was used to detect whether hemodynamics and SEMG variables differed between weeks. Spearman's correlation coefficient was used to verify linear correlation between hemodynamics and SEMG variables. Otherwise indicated, values are shown as median and ranges. All analyses were performed with SPSS 17.0 for Windows. The level of statistical significance adopted was $\mathrm{p}<0.05$.

\section{Results}

Data from the normalized maximum voluntary contraction $\left(\mathrm{MVC}_{\%}\right)$ are presented in Graphic 1. A significant improvement $(\mathrm{p}=0.04)$ on $\mathrm{MVC}_{\%}$ was observed over the training program, especially at the third and fourth weeks $(108.7 \%$, ranging from 80.4 to $122.9 \%$ at the third, and $107.0 \%$, ranging from 90.0 to $114.6 \%$ at the fourth). $\mathrm{RMS}_{\% \mathrm{VM}}$ as well as $\mathrm{RMS}_{\% \mathrm{VL}}$ did not change throughout the training program $(\mathrm{p}=$ 0.94 and $p=0.40$, respectively).

A typical fatigue plot is presented in Graphic 2 . Note the expected positive and negative slopes of
RMS and MDF, respectively. Graphic 3 depicts the boxplots of the MDF $\mathrm{VM}_{\mathrm{V} \text {-INTERCEPT }}$ and MDF $\mathrm{VLINTERCEPT}_{\text {. Note }}$ that no significant differences $(\mathrm{p}=0.63$ and $\mathrm{p}=0.14$, respectively) were observed on those variables during the follow-up.

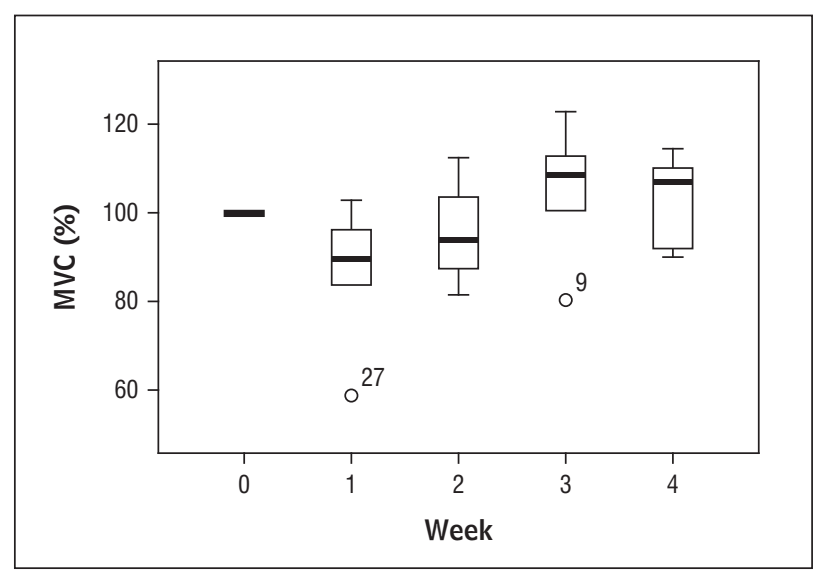

Graphic 1 - Maximum voluntary contraction

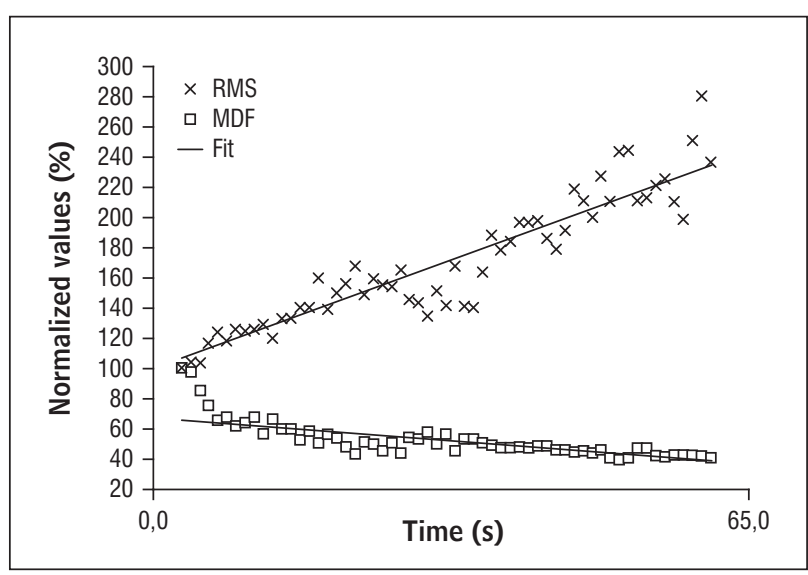

Graphic 2 - A typical fatigue plot

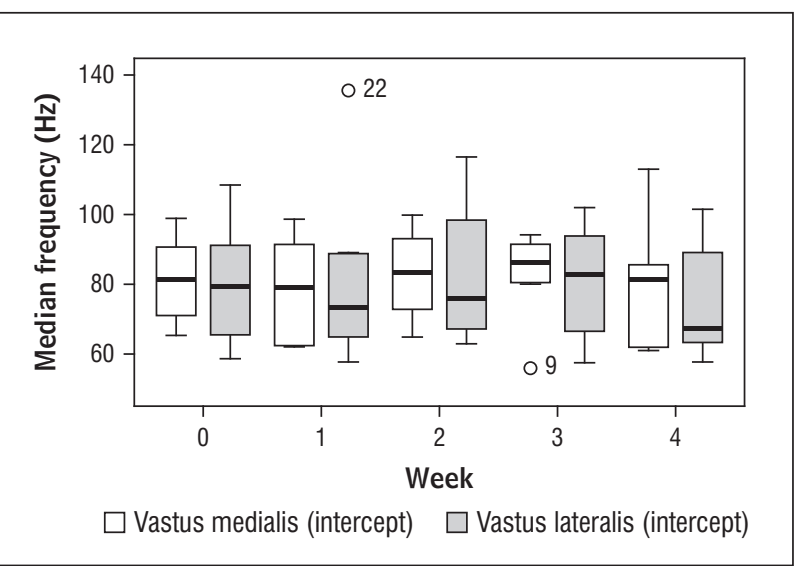

Graphic 3 - MDF $F_{\text {VM-INTERCEPT }}$ and MDF $F_{\text {VL-INTERCEPT }}$ 
Hemodynamic parameters are presented in Table 2. No significant difference in systolic $(p=0.21)$ as well as diastolic pressure ( $p=0.27)$, and heart rate $(p=0.78)$ was observed throughout the training program. Additionally, no significant correlation was observed between systolic as well as diastolic pressure and $\mathrm{MVC}_{\%}(-0.17, \mathrm{p}=0.20 ;-0.20, \mathrm{p}=0.17$; respectively), $\mathrm{RMS}_{\% \mathrm{VM}}(0.25, \mathrm{p}=0.10 ; 0.24, \mathrm{p}=0.11$; respectively) or $\mathrm{RMS}_{\% \mathrm{VL}}(-0.07, \mathrm{p}=0.36 ; 0.17, \mathrm{p}=$ 0.21 ; respectively). Moreover, heart rate was significantly correlated with $\mathrm{RMS}_{\% \mathrm{VL}}(0.56, \mathrm{p}=0.001)$, $\mathrm{MDF}_{\mathrm{VM} \text {-INTERCEPT }}(-0.41, \mathrm{p}=0.02)$, and $\mathrm{MDF}_{\mathrm{VL-INTERCEPT}}$ $(-0.67, \mathrm{p}<0.001)$.

\section{Discussion}

In this study, we evaluated the acute effects and potential risks of a four-week resistance exercise program in subjects with resistant primary hypertension. Six patients were enrolled in the training program and the muscle strength as well as fatigue tolerance were evaluated using SEMG. Additionally, the effects of the applied training program on hemodynamic variables (arterial blood pressure and heart rate) were assessed throughout the training period. The main findings of the present study were that: 1) a significant increase in quadriceps strength without significant improvement in fatigue tolerance was observed; 2) no significant changes in hemodynamic variables were observed during the short-time program of quadriceps anaerobic exercise; 3) no potential risks related to the primary disease and associated with the training program were observed.

The quadriceps strength and fatigue tolerance have been studied and associated with overall functional capacity and independency (23). A trend of reduction of the quadriceps strength was described in patients with hypertension. This adaptation is probably related to local changes in the fiber type proportion and area of the VL muscle $(9,24)$ rather than a systemic adaptation. Recently a tissue-specific effect of angiotensin II in the skeletal muscle cell was described (25). Accordingly, the release of angiotensin II seems to contribute to an increase in lactate/pyruvate ratio caused by an impairment of glucose supply to the skeletal muscle. As a consequence, hypertension may lead to muscle disuse and impairment of functional capacity. In this scenario, the regular practice of exercise can be an important coadjutant treatment in patients with resistant hypertension.

As expected, a significant increase in quadriceps strength was observed even with a sub-maximal resistance exercise program. Changes in $\mathrm{MVC}_{\%}$ but not in $\mathrm{RMS}_{\% \mathrm{VM}}$ and $\mathrm{RMS}_{\% \mathrm{VL}}$ suggest that the increase in muscle force was not accompanied by motor learning $(22,26)$. No significant difference was observed in $\mathrm{MDF}_{\mathrm{VM} \text {-INTERCEPT }}$ and $\mathrm{MDF}_{\mathrm{VL-INTERCEPT}}$ values during the four-week follow-up. Lactic acid accumulation determines a decrease in muscle conduction velocity, and thus in MDF. The percentage of type II muscle fibers is positively correlated with lactate accumulation, and both are negatively correlated with MDF intercept values $(22,27)$. Thus it is suggested that no significant changes occurred in fiber type composition in the studied subjects. The significant correlations found between heart rate and MDF intercept values for both muscles (MDF $\mathrm{MM}_{\mathrm{VM} \text {-INTERCEPT }}$ and $\mathrm{MDF}_{\mathrm{VL} \text {-INTERCEPT }}$ ) suggests that quadriceps endurance may be accompanied by a reduction of rest heart rate, which is associated with cardiovascular risk events (28).

The proposed program did not expose the subjects to an increased risk during exercises mainly due

Table 2 - Hemodynamic parameters

\begin{tabular}{|c|c|c|c|c|c|c|}
\hline & Week 0 & Week 1 & Week 2 & Week 3 & Week 4 & $\mathrm{p}$ value \\
\hline Systolic pressure, $\mathrm{mmHg}$ & $\begin{array}{c}173 \\
(140-230)\end{array}$ & $\begin{array}{c}173 \\
(140-180)\end{array}$ & $\begin{array}{c}160 \\
(150-177)\end{array}$ & $\begin{array}{c}172 \\
(120-190)\end{array}$ & $\begin{array}{c}173 \\
(115-190)\end{array}$ & 0.21 \\
\hline Diastolic pressure, $\mathrm{mmHg}$ & $\begin{array}{c}100 \\
(90-170)\end{array}$ & $\begin{array}{c}103 \\
(80-145)\end{array}$ & $\begin{array}{c}108 \\
(90-120)\end{array}$ & $\begin{array}{c}120.0 \\
(65-150)\end{array}$ & $\begin{array}{c}103 \\
(70-145)\end{array}$ & 0.27 \\
\hline Heart rate, beats/min & $\begin{array}{c}67 \\
(46-82)\end{array}$ & $\begin{array}{c}64 \\
(46-90)\end{array}$ & $\begin{array}{c}63 \\
(52-78)\end{array}$ & $\begin{array}{c}60 \\
(52-78)\end{array}$ & $\begin{array}{c}58 \\
(50-78)\end{array}$ & 0.78 \\
\hline
\end{tabular}

Source: Research data. 
to sub-maximal load, suggesting the relative safety of the proposed protocol. One patient of the group experienced a single episode of knee joint discomfort, but did not interrupt the exercise program and did not required physiotherapy. Another patient presented symptoms of heart failure due to the lack of adherence to pharmacological treatment and was excluded during the follow-up. Almost all volunteers referred short-time muscle soreness, an expected complains for resistance exercises. No report of dyspnea was made by the studied group. Gains in exercise performance may be limited in a home-based rehabilitation program. However, exercise training at home may lead to a better long-term adherence to an exercise program because the lifestyle change occurs in a familiar environment.

\section{Limitations of the study}

The small sample size does not allow the generalization of the results. However, this study may provide data for proper calculation of sample sizes for larges studies in this topic. Moreover, the concomitant pharmacological treatment introduces a bias on cardiovascular or SEMG variables. Additionally, the potential benefits of the improvement of muscle strength on day-life activities still need to be addressed on this population. Additionally, recommendations for progressive resistance exercise were followed (13). The protocol used in this study was consistent with a resistance exercise (17). However, the intensity of exercises was "under-dosed" (3 kg represents almost 6\% of median $100 \%$ MVC at Week 0) as a precaution not to harm patients but at a cost of possibly reduced its effectiveness. Additionally, given the wide variation in size and age of subjects the variation in the stimulus that each subject received for the monitored adaptations may be significant.

\section{Conclusion}

The prescribed protocol seemed to increase successfully localized muscle strength without hazardous effects on cardiovascular variables in patients with resistant hypertension under pharmacological treatment. No significant changes were observed in arterial blood pressure and heart rate throughout the applied training program period.

\section{References}

1. Avolio A. Genetic and environmental factors in the function and structure of the arterial wall. Hypertension. 1995;26(1):34-7.

2. Chobanian AV, Bakris GL, Black HR, Cushman WC, Green LA, Izzo JL, et al. The seventh report of the joint national committee on prevention, detection, evaluation, and treatment of high blood pressure: the JNC 7 report. JAMA. 2003;289(19):2560-72.

3. Alper AB Jr, Calhoun DA. Contemporary management of resistant hypertension. Cur Hypertens Rep. 1999; 1(5):402-7.

4. Alderman $\mathrm{MH}$, Budner $\mathrm{N}$, Cohen $\mathrm{H}$, Lamport B, Ooi WL. Prevalence of drug resistant hypertension. Hypertension. 1988;11(3 Pt 2):II71-5.

5. Braunwald E. Heart disease: a textbook of cardiovascular medicine. Philadelphia, W. B.: Saunders Company; 1992.

6. Khder Y, Bray-Desboscs L, Aliot E, Zannad F. Effects of blood pressure control on radial artery diameter and compliance in hypertensive patients. Am J Hypertens. 1997;10(3):269-74.

7. Ferreira AS, Santos MAR, Barbosa J Filho, Cordovil I, Souza MN. Determination of radial artery compliance can increase the diagnostic power of pulse wave velocity measurement. Physiol Meas. 2004;25(1): 37-50.

8. Heistad DD, Armstrong ML, Baumbach GL, Faraci FM. Sick Vessel Syndrome. Recovery of Atherosclerotic and Hypertensive Vessels. Hypertension. 1995;26(3): 509-13.

9. Hernández N, Torres SH, Finol HJ, Vera O. Capillary changes in skeletal muscle of patients with essential hypertension. Anat Rec. 1999;256(4):425-32.

10. Antonios TFT, Singer DRJ, Markandu ND, Mortimer PS, MacGregor GA. Structural skin capillary rarefaction in essential hypertension. Hypertension. 1999; 33(4):998-1001.

11. Booth FM, Chakravarthy MV, Gordon SE, Spangenburg EE. Waging war on physical inactivity: using modern molecular ammunition against an ancient enemy. J Appl Physiol. 2002;93(1):3-30. 
12. Pollock ML, Franklin BA, Balady GJ, Chaitman BL, Fleg JL, Fletcher B, et al. Resistance exercise in individuals with and without cardiovascular disease benefits, rationale, safety, and prescription an advisory from the committee on exercise, rehabilitation, and prevention, council on clinical cardiology, American Heart Association. Circulation. 2000;101(7):828-33.

13. Taylor NF, Dodd KJ, Damiano DL. Progressive resistance exercise in physical therapy: a summary of systematic reviews. Phys Ther. 2005;85(11):1208-23.

14. Pollock ML, Franklin BA, Balady GJ, Chaitman BL, Fleg JL, Fletcher B, et al. AHA Science Advisory. Resistance exercise in individuals with and without cardiovascular disease: benefits, rationale, safety, and prescription. Circulation. 2000;101(7):828-33.

15. Lindeman E, Spaans F, Reulen J, Leffers P, Drukker J. Progressive resistance training in neuromuscular patients effects on force and surface EMG. J Electromyogr Kinesiol. 1999;9(6):379-84.

16. Pincivero DM, Campy RM, Salfetnikov Y, Bright A, Coelho AJ. Influence of contraction intensity, muscle, and gender on median frequency of the quadriceps femoris. J Appl Physiol. 2001;90(3):804-10.

17. Kraemer WJ, Adams K, Cafarelli E, Dudley GA, Dooly C, Feigenbaum MS, et al. American College of Sports Medicine position stand on progression models in resistance training for healthy adults. Med Sci Sports Exerc. 2002;34(2):364-80.

18. Hermens HJ, Freriks B, Disselhorst-Klug C, Rau G. Development of recommendations for SEMG sensors and sensor placement procedures. J Electromyogr Kinesiol. 2000;10(5):361-74.

19. Lee HD, Suter E, Herzog W. Force depression in human quadriceps femoris following voluntary shortening contractions. J Appl Physiol. 1999;87(5):1651-5.

20. Rainoldi A, Galardi G, Maderna L, Comi G, Lo Conte LR, Merletti R. Repeatability of surface EMG variables during voluntary isometric contractions of the biceps brachii muscle. J Electromyogr Kinesiol. 1999;9(2):105-19.
21. Farina D, Merletti R. Comparison of algorithms for estimation of EMG variables during voluntary isometric contractions. J Electromyogr Kinesiol. 2000; 10(5):337-49.

22. Merletti R, Parker P. Electromyography: physiology, engineering and physical applications. New Jersey: John Wiley \& Sons, Inc.; 2004.

23. Jankowska EA, Wegrzynowska K, Superlak M, Nowakowska K, Lazorczyk M, Biel B, et al. The 12week progressive quadriceps resistance training improves muscle strength, exercise capacity and quality of life in patients with stable chronic heart failure. Int J Cardiol. 2008;130(1):36-43.

24. Henrich HA, Romen W, Heimgärtner W, Hartung E, Bäumer F. Capillary rarefaction characteristic of the skeletal muscle of hypertensive patients. Klin Wochenschr. 1988;66(2):54-60.

25. Boschmann M, Jordan J, Adams F, Christensen NJ, Tank J, Franke G, et al. Tissue-specific response to interstitial angiotensin II in humans. Hypertension. 2003;41(1):37-41.

26. Farina D, Merletti R, Enoka RM. The extraction of neural strategies from the surface EMG. J Appl Physiol. 2004;96(4):1486-95.

27. Gerdle B, Henriksson-Larsen K, Lorentzon R, Wretling ML. Dependence of the mean power frequency of the electromyogram on muscle force and fiber type. Acta Physiol Scand. 1991;142(4):457-65.

28. Singh BN. Increased heart rate as a risk factor for cardiovascular disease. Eur Heart J. 2003;5 (Supplement G):G3-9.

Received: 10/21/2010

Recebido: 21/10/2010

Approved: 04/21/2011

Aprovado: 21/04/2011 